\title{
HUBUNGAN POLA KONSUMSI SUMBER ZAT BESI, INHIBITOR DAN ENHANCER ZAT BESI DENGAN KEJADIAN ANEMIA PADA SANTRIWATI PONDOK PESANTREN AL-MIZAN MUHAMMADIYAH LAMONGAN
}

\author{
Correlation between Consumption Patterns of Iron Sources, Iron Inhibitor, and Iron Enhancer \\ with the Occurence of Anemia Among Female Students in Islamic Boarding School Al-Mizan \\ Muhammadiyah Lamongan \\ Fanti Septia Nabilla $^{1^{*}}$, Lailatul Muniroh ${ }^{1}$, Mahmud Aditya Rifqi $^{1}$ \\ ${ }^{1}$ Program Studi S1 Gizi, Departemen Gizi Kesehatan, Fakultas Kesehatan Masyarakat, Universitas Airlangga, Surabaya, \\ Indonesia \\ *E-mail: nabilla.septia20@gmail.com
}

\begin{abstract}
ABSTRAK
Anemia merupakan salah satu permasalahan defisiensi zat gizi yang rentan dialami oleh remaja putri. Anemia adalah kondisi dimana kadar hemoglobin $(\mathrm{Hb})$ lebih rendah dari $12 \mathrm{~g} / \mathrm{dL}$. Anemia dapat disebabkan karena kekurangan darah, penyakit infeksi, rendahnya kandungan zat besi pada makanan, rendahnya konsumsi makanan sumber zat besi dan terdapat zat yang dapat menghambat absorbsi zat besi pada makanan. Mengonsumsi sumber zat besi dan enhancer zat besi serta mengurangi konsumsi inhibitor dapat meningkatkan absorbsi zat besi dalam tubuh. Penelitian ini bertujuan untuk menganalisis hubungan antara pola konsumsi sumber zat besi, inhibitor zat besi dan enhancer zat besi dengan kejadian anemia pada santriwati. Penelitian ini menggunakan desain cross sectional pada 50 santriwati kelas X dan XI di Pondok Pesantren Al-Mizan Muhammadiyah Lamongan. Pemilihan sampel menggunakan metode proportional random sampling. Kadar hemoglobin diukur menggunakan alat hemoglobinmeter digital dan data pola konsumsi dikumpulkan menggunakan food frequency questionnaire. Analisis data menggunakan uji korelasi Spearman. Penelitian ini menemukan hubungan antara pola konsumsi sumber zat besi $(\mathrm{p}=0,036)$ dan inhibitor zat besi $(\mathrm{p}=0,012)$ dengan kejadian anemia. Tidak ada hubungan antara pola konsumsi enhancer zat besi $(\mathrm{p}=0,339)$ dengan kejadian anemia. Kebiasaan mengonsumsi sumber zat besi dan inhibitor zat besi dapat meningkatkan kadar zat besi dalam tubuh terutama zat besi heme dan mengurangi konsumsi pangan inhibitor zat besi untuk menurunkan risiko terjadinya anemia.
\end{abstract}

Kata kunci : anemia, pola konsumsi, enhancer, inhibitor, zat besi, remaja

\section{ABSTRACT}

One of the nutrient deficiency problems for adolescent girls is anemia. Anemia is a condition occurs when the hemoglobin (Hb) level is below $12 \mathrm{~g} / \mathrm{dL}$. Anemia can be caused by blood deficiency, infections;low iron contens in the diet, low consumption of food source of iron and the presence of any substances that might inhibit the absorption of iron intake from foods. Consuming iron source foods and iron enhancers, also reducing iron inhibitor intake can enhance iron absorption in body. The obstruction of iron absorption in body can increase the risk of anemia for adolescent girls. This study aimed to analyze the correlation between consumption patterns of iron sources, iron inhibitor, and iron enhancer, with the occurrence of anemia among adolescent girls. This research was an analytic observational study that performed cross-sectional design on 50 female students from grade X to XI at Islamic Boarding School AlMizan Muhammadiyah Lamongan. The participants were selected based on proportional random sampling method. The hemoglobin levels data were collected using digital hemoglobinmeter and the consumption patterns data were collected using food frequency questionnaire. Spearman correlation test was performed to analyze the data. The results showed there was a correlation between consumption patterns of iron source $(p=0.036)$ and iron inhibitor $(p=0.012)$ with the occurrence of anemia. However, there was no correlation between consumption patterns of iron enhancers $(p=0.339)$ with the occurrence of anemia. In conclusion, a habit of consuming iron-rich-foods and iron inhibitor in diets contributes to the occurrence of anemia in female students. Therefore, they are expected to consume more ironrich foods especially heme iron and minimalize consuming iron inhibitor foods to decrease the risk of anemia.

Keywords: anemia, consumption patterns, enhancer, inhibitor, iron, adolescent 


\section{INTRODUCTION}

Anemia yaitu kondisi kurangnya total sel darah merah atau kadar hemoglobin sebagai carrier oksigen dalam darah sehingga kebutuhan fisiologis tubuh tidak tercukupi (Riskesdas, 2013). World Health Organization (WHO, 2013) menyatakan bahwa di dunia prevalensi anemia sebanyak 4088\%. Berdasarkan Riset Kesehatan Dasar tahun 2013 diketahui bahwa kejadian anemia pada perempuan yaitu sebesar $23,9 \%$ dan mengalami peningkatan menjadi $27,2 \%$ pada tahun 2018 (Riskesdas, 2018).

Anemia dapat terjadi dikarenakan beberapa faktor diantaranya terdapat peningkatan kebutuhan tubuh, kekurangan sel darah merah, derajat sosial dan ekonomi, kandungan zat besi yang rendah dalam makanan yang dikonsumsi, rendahnya penyerapan zat besi, rendahnya pengetahuan mengenai zat besi, serta adanya inhibitor absorbsi zat besi dalam makanan (Puji et al., 2010). Rendahnya kandungan zat besi dalam makanan dapat menyebabkan defisiensi asupan zat besi, yang apabila terjadi secara terus menerus dapat menyebabkan berkurangnya cadangan besi dalam tubuh sehingga sintesis hemoglobin dapat terganggu (Sya'bani et al., 2016). Faktor yang menjadi pendorong (enhancer) dan penghambat (inhibitor) penyerapan zat besi dari makanan harus diperhatikan untuk menilai asupan zat besi. Menurut Marya (2013) vitamin C, vitamin A dan vitamin B2 merupakan beberapa zat gizi yang dapat membantu penyerapan dari zat besi. selain itu, protein hewani yang berasal dari daging, ikan dan unggas merupakan faktor enhancer zat besi yang berperan dalam hematopoisis yaitu pembentukan eritrosit dengan hemoglobin (Sembiring, 2017). Namun, terdapat pula zat yang berperan sebagai inhibitor zat besi sehingga penyerapan zat besi menjadi terganggu atau terhambat. Zat gizi dalam makanan yang dapat berperan sebagai inhibitor zat besi yaitu fosfat, kalsium, tanin dan fitat apabila dalam besaran yang banyak dikonsumsi (Sizer $e t$ al., 2013).

Penelitian yang dilakukan oleh Sya'bani et al. (2016) menunjukkan bahwa tingkat kecukupan zat besi berhubungan langsung dengan status anemia. Sebesar $62 \%$ santriwati yang mengalami anemia memiliki tingkat konsumsi zat besi yang tergolong kurang. Penelitian ini selaras dengan
Sembiring (2017) pada siswi SMA Negeri 1 Lubuk Pakam menyatakan siswi yang mengalami anemia sebesar $90,5 \%$ biasa mengonsumsi pangan sumber inhibitor zat besi dan sebesar $84,4 \%$ siswi tidak pernah mengonsumsi pangan sumber enhancer zat besi mengalami kejadian anemia.

Salah satu kelompok usia yang rawan mengalami anemia adalah remaja putri (Soetjiningsih, 2010). Banyaknya remaja putri yang mengalami anemia dikarenakan siklus menstruasi setiap bulan. Menurut Marmi (2013) ketersediaan pangan dan pola makan yang salah dapat menyebabkan kurangnya asupan zat gizi sehari-hari sehingga terjadi anemia. Selain itu, penyebab lain anemia pada remaja putri yaitu ingin memiliki bentuk tubuh ideal dengan melakukan diet ketat yang dapat menyebabkan kurangnya asupan makanan seimbang dan bergizi (Sayogo, 2011).

Santriwati merupakan salah satu kelompok yang rentan mengalami anemia. Santriwati adalah panggilan bagi siswi yang bermukim di pondok pesantren untuk menimba ilmu-ilmu agama. Jauh dari orang tua membuat santriwati dituntut untuk hidup mandiri terutama dalam memenuhi kebutuhan makanannya. Menurut Chairunnisa et al. (2019) tinggi konsumsi jajanan ringan dan rendah konsumsi sayuran merupakan kebiasaan makan santriwati yang kurang tepat. Hasil penelitian yang dilakukan oleh Emilia (2019) di Pondok Pesantren Hidayatussalikin Air Itam Pangkalpinang menyatakan $63,8 \%$ santri putri mengalami anemia. Menurunnya konsentrasi dalam belajar merupakan salah satu akibat dari terjadinya anemia pada remaja (Adriani et al., 2012).

Berdasarkan studi pendahuluan yang dilakukan pada bulan Februari 2020 di Pondok Pesantren Al-Mizan Muhammadiyah Lamongan dengan sampel 10 santriwati diperoleh hasil sebesar 70\% santriwati tidak mengetahui apa penyebab anemia, $80 \%$ santriwati tidak mengetahui bahan pangan sumber zat besi dan $100 \%$ santriwati pernah mengalami gejala anemia 5L (lemah, letih, lesu, lunglai dan lelah). Berdasarkan data tersebut, maka diperlukan adanya penelitian untuk mengetahui hubungan antara pola konsumsi sumber, inhibitor dan enhancer zat besi dengan kejadian anemia pada santriwati di Pondok Pesantren Al-Mizan Muhammadiyah Lamongan. 


\section{METODE}

Penelitian ini merupakan penelitian observasional analitik dengan menggunakan desain cross sectional. Populasi pada penelitian merupakan santriwati kelas X dan XI di Pondok Pesantren Al-Mizan Muhammadiyah Lamongan sebanyak 101 orang. Banyaknya sampel dalam penelitian ini adalah 50 santriwati dengan rentang usia 15-18 tahun. Penentuan dan pengambilan sampel populasi masing-masing kelas dilakukan secara proportional random sampling.

Pengambilan data dilangsungkan pada Bulan Juli 2020 di Pondok Pesantren Al-Mizan Muhammadiyah Lamongan. Variabel yang diteliti adalah pola konsumsi santriwati selama di pondok pesantren yang meliputi kebiasaan konsumsi pangan sumber zat besi, inhibitor zat besi dan enhancer zat besi. data mengenai pola konsumsi pangan sumber zat besi, inhibitor zat besi dan enhancer zat besi diperoleh melalui wawancara menggunakan alat bantu Food Frequency Questionare (FFQ) selama 1 bulan terakhir. Frekuensi pola konsumsi dikategorikan menjadi: (1) Biasa dikonsumsi apabila skor $\geq 15-50$, (2) Kadang-kadang apabila skor $\geq 10-14,9$, (3) Tidak pernah apabila skor $\geq 1-9,9$ (Widajanti, 2009).

Dilakukan pemeriksaan kadar hemoglobin pada santriwati menggunakan hemoglobinmeter dengan merk easy touch untuk mengetahui status anemia pada santriwati. Pemeriksaan dilakukan oleh tenaga kesehatan yaitu perawat. Hasil pemeriksaan hemoglobin dikategorikan menjadi : (1) Anemia apabila skor $\mathrm{Hb}<12 \mathrm{~g} / \mathrm{dL}$, (2) Tidak anemia apabila skor $\mathrm{Hb} \geq 12 \mathrm{~g} / \mathrm{dL}$ (Proverawati et al., 2011). Data pada penelitian ini dilakukan analisis statistik menggunakan uji korelasi Spearman dengan tingkat signifikansi $\alpha=0,05$. Penelitian ini telah mendapatkan persetujuan dari Komisi Etik Fakultas Keperawatan Universitas Airlangga dengan nomor sertifikat 1972-KEPK tahun 2020 .

\section{HASIL DAN PEMBAHASAN}

Tabel 1 menunjukkan bahwa sebagian besar responden merupakan kategori usia remaja akhir dengan rentang usia 16-19 tahun yaitu sebesar 96,0\%. Remaja perempuan merupakan kelompok usia yang berisiko mengalami anemia. Perempuan yang menstruasi cenderung kekurangan zat besi karena kehilangan zat besi yang terjadi setiap bulannya (Corwin, 2009). Berkurangnya kadar hemoglobin yang berlangsung dalam kurun waktu yang lama dapat menyebabkan terjadinya anemia (Brown et al. , 2011).

Karakteristik responden yang lainnya yaitu uang saku yang digunakan untuk makan dan jajan dalam satu hari. Rata-rata uang saku santriwati dalam satu hari Rp. $6.240 \pm 2.403$ dengan uang saku minimum Rp. 2.000 dan uang saku maksimum Rp. 10.000. Tabel 1 menunjukkan sebesar $62,0 \%$ santriwati memiliki besaran uang saku yang kurang dari rata-rata. Pemenuhan zat gizi dan konsumsi pangan sumber zat besi dipengaruhi oleh keterbatasan uang saku pada remaja yang menyebabkan remaja hanya dapat membeli snack (Astuti et al., 2016).

Tabel 1 menunjukkan sebesar 22,0\% santriwati di Pondok Pesantren Al-Mizan mengalami anemia. Sebagian besar santriwati berstatus gizi normal. Rata-rata kadar hemoglobin santriwati sebesar 13,34 g/dL dengan nilai minimum sebesar 10,9 g/ dL dan nilai maksimum sebesar $16,4 \mathrm{~g} / \mathrm{dL}$. Pada penelitian ini santriwati yang mengalami anemia dengan kadar hemoglobin $<12$ g/dL sebesar $22 \%$. Prevalensi remaja anemia pada penelitian ini lebih tinggi dibandingkan dengan prevalensi anemia

Tabel 1. Distribusi Karakteristik Individu di Pondok Pesantren Al-Mizan Muhammadiyah Lamongan Tahun 2020.

\begin{tabular}{lcc}
\hline \multicolumn{1}{c}{ Karakteristik Individu } & n & (\%) \\
\hline Usia (Tahun) & & \\
$\quad$ Remaja Awal (10-12) & 0 & 0,0 \\
Remaja Madya (13-15) & 2 & 4,0 \\
Remaja Akhir (16-19) & 48 & 96,0 \\
Uang Saku (Rupiah) & & \\
$\quad \leq$ Rata-rata ( $\leq$ Rp 6.240) & 31 & 62,0 \\
$\quad \geq$ Rata-rata ( $\geq$ Rp 6.240) & 19 & 38,0 \\
Status Anemia (Hb) & & \\
Anemia (<12 g/dL) & 11 & 22,0 \\
Tidak Anemia ( $\geq 12$ g/dL) & 39 & 78,0 \\
Status Gizi & & \\
Sangat Kurus & 2 & 4,0 \\
Kurus & 1 & 2,0 \\
Normal & 32 & 64,0 \\
Gemuk & 8 & 16,0 \\
Obesitas & 7 & 14,0 \\
\hline
\end{tabular}


remaja menurut Riset Kesehatan Dasar tahun 2018 yaitu sebesar 8,1\%. Akan tetapi, prevalensi remaja anemia penelitian ini lebih rendah bila dibandingkan dengan prevalensi anemia pada remaja putri di SMA Negeri 3 Kendari yang sebesar 41,7\% (Kaimudin et al., 2017). Anemia dapat disebabkan karena rendahnya kandungan zat besi dalam makanan (Puji et al., 2010). Zat besi dapat berperan dalam respirasi seluler sebagai bagian dari hemoglobin dan mioglobin serta membentuk hemoglobin dari eritrosit (Beck et al., 2011).

Rata-rata persen kecukupan zat gizi dikelompokkan menjadi kurang $(<80 \% \mathrm{AKG})$, cukup (80-110\% AKG) dan lebih ( $>110 \%$ AKG). Tabel 2 menunjukkan rata-rata persen kecukupan protein, zat besi dan vitamin $\mathrm{C}$ santriwati tergolong dalam kategori kurang $(<80 \% \mathrm{AKG})$.

Makanan sumber zat besi pada penelitian ini yaitu sayuran hijau seperti bayam, kangkung, sawi, kacang hijau, kacang tanah (beserta olahannya), seafood (kerang dan udang). Sumber zat besi yang sering dikonsumsi yaitu kacang hijau dan kacang tanah (beserta olahannya). Santriwati juga mengonsumsi tablet tambah darah yang didapatkan dari pondok pesantren. Makanan inhibitor zat besi pada penelitian ini meliputi bahan makanan sumber oksalat, tanin, fitat dan kalsium. Sumber inhibitor yang sering dikonsumsi oleh santriwati yaitu tahu dan tempe. Daging, ikan, ayam dan vitamin $\mathrm{C}$ yang terkandung dalam buah dan sayur merupakan bahan makanan enhancer zat besi pada penelitian ini. Sumber enhancer zat besi yang sering dikonsumsi yaitu ikan pindang, ayam dan telur.

Hasil analisis uji hubungan antara pola konsumsi sumber zat besi dengan status anemia menghasilkan nilai $p$-value $\leq 0,05 \quad(p=0,036)$ berarti diperoleh hubungan yang bermakna antara pola konsumsi sumber zat besi dengan kejadian anemia santriwati di Pondok Pesantren Al-Mizan. Tingginya kejadian anemia dapat dikarenakan

Tabel 2. Distribusi Presentase Kecukupan Konsumsi Santriwati di Pondok Pesantren Al-Mizan Muhammadiyah Lamongan Tahun 2020.

\begin{tabular}{lcc}
\hline Persen Kecukupan & Rata-rata & Kategori Kecukupan \\
\hline Protein (\%) & 55,37 & Kurang $(<80 \%)$ \\
Zat Besi (\%) & 28,13 & Kurang $(<80 \%)$ \\
Vitamin C (\%) & 44,87 & Kurang $(<80 \%)$ \\
\hline
\end{tabular}

jarangnya mengonsumsi makanan sumber zat besi yang mengakibatkan rendahnya hemoglobin dalam tubuh.

Rendahnya konsumsi sumber zat besi pada penelitian ini disebabkan terbatasnya ketersediaan pangan sumber zat besi heme yang disediakan oleh pondok. Selain itu, kantin di pondok pesantren hanya menjual makanan dan minuman ringan serta tidak diperkenankan untuk menjual makanan berat seperti nasi beserta lauk pauk dimana lauk pauk merupakan salah satu sumber zat besi. Sebagian besar santriwati lebih sering mengonsumsi pangan sumber zat besi non heme yaitu kacang tanah dan kacang hijau. Sumber pangan tersebut sebagian besar diperoleh dari jajanan seperti bubur kacang hijau dan bumbu pentol atau batagor yang hanya bisa dibeli saat jam istirahat sekolah dan didapatkan dari penjual di depan sekolah. Setelah menyelesaikan jam sekolah dan kembali ke pondok, santriwati tidak diperkenankan untuk membeli jajanan yang dijual di depan sekolah. Santriwati lebih sering mengonsumsi pangan sumber zat besi non-heme dengan bioavabilitas yang rendah dikarenakan adanya zat asam fitat dan oksalat yang dapat mengikat zat besi serta menghambat penyerapannya, sehingga hanya

Tabel 3. Hubungan Pola Konsumsi Sumber Zat Besi, Inhibitor Zat Besi dan Enhancer Zat Besi dengan Kejadian Anemia Santriwati di Pondok Pesantren Al-Mizan Muhammadiyah Lamongan Tahun 2020.

\begin{tabular}{|c|c|c|c|c|c|}
\hline \multirow{3}{*}{ Variabel } & \multicolumn{4}{|c|}{ Status Anemia } & \multirow{3}{*}{ p value } \\
\hline & \multicolumn{2}{|c|}{ Anemia } & \multicolumn{2}{|c|}{$\begin{array}{c}\text { Tidak } \\
\text { Anemia }\end{array}$} & \\
\hline & $\mathbf{n}$ & $(\%)$ & $\mathbf{n}$ & $(\%)$ & \\
\hline \multicolumn{6}{|c|}{ Pola Konsumsi Sumber Zat Besi } \\
\hline Tidak Pernah & 10 & 31,2 & 22 & 68,8 & \multirow{3}{*}{$0,036^{*}$} \\
\hline Kadang-kadang & 1 & 5,6 & 17 & 94,4 & \\
\hline Biasa Konsumsi & 0 & 0,0 & 0 & 0,0 & \\
\hline \multicolumn{6}{|l|}{ Inhibitor Zat Besi } \\
\hline Tidak Pernah & 4 & 12,1 & 29 & 87,9 & \multirow{3}{*}{$0,012 *$} \\
\hline Kadang-kadang & 6 & 37,5 & 10 & 62,5 & \\
\hline Biasa Konsumsi & 1 & 100,0 & 0 & 0,0 & \\
\hline \multicolumn{6}{|l|}{ Enhancer Zat Besi } \\
\hline Tidak Pernah & 10 & 20,8 & 38 & 79,2 & \multirow{3}{*}{0,339} \\
\hline Kadang-kadang & 1 & 50,0 & 1 & 50,0 & \\
\hline Biasa Konsumsi & 0 & 0,0 & 0 & 0,0 & \\
\hline
\end{tabular}


sedikit total zat besi yang terserap oleh tubuh (Husnah et al., 2014).

Hasil penelitian ini selaras dengan Junengsih, et al. (2017) yang menyebutkan bahwa remaja perempuan dengan asupan zat besi yang rendah memiliki risiko 7,9 kali lebih tinggi mengalami anemia. Adanya hubungan bermakna antara asupan zat besi dengan status anemia pada siswi MTs Ciwandan (Pratiwi, 2016).

Hasil analisis uji hubungan antara pola konsumsi pangan sumber inhibitor zat besi dengan status anemia diperoleh nilai $\mathrm{p} \leq 0,05(\mathrm{p}=0,012)$ berarti ada hubungan antara pola konsumsi sumber inhibitor zat besi dengan kejadian anemia pada santriwati di Pondok Pesantren Al-Mizan. Semakin jarang santriwati mengonsumsi inhibitor zat besi maka prevalensi santriwati yang tidak anemia juga semakin tinggi. Hal tersebut dikarenakan hampir setiap hari menu di pondok pesantren menyediakan olahan tahu dan tempe. Tahu dan tempe berbahan dasar kacang kedelai yang mengandung zat fitat, dimana zat fitat ini dapat mengikat zat besi sehingga mempersulit penyerapannya. Jajanan berbahan cokelat sering dikonsumsi santriwati dikarenakan mudah ditemukan di kantin serta memiliki harga yang cukup murah, padahal cokelat mengandung asam oksalat yang bisa mengurangi absorbsi zat besi. selain itu, santriwati juga sering mengonsumsi susu yang mengandung kalsium, dimana kalsium apabila berinteraksi dengan zat besi dapat menghambat penyerapan zat besi yang terjadi di mukosa usus (Marina et al., 2015). Kalsium terbukti mempengaruhi penyerapan zat besi, dimana efek negatif status zat besi lebih rentan pada kelompok dengan konsumsi kalsium tingkat tinggi (Kwatra, 2019). Hasil penelitian selaras dengan penelitian Penelitian Jaelani, et al. (2017) menyatakan terdapat hubungan pola konsumsi makanan inhibitor dengan kejadian anemia pada remaja putri, kejadian anemia akan semakin tinggi apabila sering mengonsumsi inhibitor penyerapan zat besi.

Hasil analisis uji hubungan antara pola konsumsi pangan sumber enhancer zat besi dengan status anemia memperoleh hasil nilai $p$-value $\geq 0,05(\mathrm{p}=0,339)$ yang berarti tidak adanya hubungan kejadian anemia dengan pola konsumsi enhancer zat besi pada santriwati. Hal tersebut dapat dikarenakan ketika santriwati mengonsumsi pangan sumber zat besi non-heme yang hanya $10 \%$ terabsorbsi oleh tubuh dan tidak dibarengi mengonsumsi pangan enhancer zat besi seperti vitamin $C$ dan protein hewani (Pratiwi, 2016). Selain itu, menu makan yang disediakan pondok hanya berupa nasi serta lauk saja, tidak ada buahbuahan, padahal buah-buahan mengandung salah satu zat pendorong absorbsi zat besi yaitu vitamin C. Sebagian besar santriwati hanya mengonsumsi buah-buahan yang didapatkan dari orang tua atau keluarga saat berkunjung. Hasil dari penelitian ini selaras dengan penelitian Pratiwi et al. (2018) yang menyebutkan tidak ditemukan hubungan kejadian anemia dengan kebiasaan mengonsumsi makanan sumber enhancer zat besi.

\section{KESIMPULAN DAN SARAN}

Berdasarkan hasil penelitian pada santriwati di Pondok Pesantren Al-Mizan Muhammadiyah Lamongan, ditemukan hubungan kebiasaan pola konsumsi pangan sumber dan inhibitor zat besi dengan kejadian anemia pada santriwati. Semakin jarang mengonsumsi inhibitor zat besi maka kadar prevalensi santriwati yang tidak anemia semakin tinggi. Selain itu, semakin jarang mengonsumsi pangan sumber zat besi menyebabkan santriwati lebih berisiko mengalami anemia. Tidak ditemukan hubungan kejadian anemia dengan pola konsumsi sumber enhancer zat besi pada santriwati. Peneliti menyarankan kepada santriwati untuk mengurangi konsumsi pangan sumber inhibitor zat besi. Santriwati diharapkan memperbanyak konsumsi sumber besi heme dengan memperbanyak asupan lauk hewani, hal tersebut dilakukan untuk mencegah terjadinya anemia pada santriwati. Selain itu, pihak pesantren dapat menyediakan makanan yang dapat mencukupi kebutuhan zat gizi para santriwati dikarenakan akses terhadap sumber makanan bergizi terbatas hanya dari pesantren. Prospek riset selanjutnya yang perlu diteliti yaitu mengenai kepatuhan mengonsumsi tablet tambah darah, mengingat pondok memiliki program pembagian tablet tambah darah.

\section{DAFTAR PUSTAKA}

Adriani, M., \& Wirjatmadi, B. (2012). Peran gizi dalam kehidupan. Jakarta: Kencana Prenada Media Group. 
Astuti, S.D., \& Trisna, E. (2016). Faktor-faktor yang berhubungan dengan kejadian anemia pada remaja putri wilayah Lampung Timur. Jurnal Keperawatan, vol 5 (2).

Balitbangkes. (2018). Hasil Riset Kesehatan Dasar (Riskesdas). Jakarta : Kementrian Kesehatan R.I.

Beck, M.E. (2011). Ilmu gizi dan diet : Hubungannya dengan penyakit-penyakit untuk perawat dan dokter. Yogyakarta : Andi Yogyakarta.

Brown, J.E., Issacs., Krinke, J.S., Lechtenberg, U.B., \& Murtaugh, E.C.M.A. (2011). Nutrition through the life cycle fourth edition. Belmout USA : Wadsworth Cengage Learning.

Chairunnisa, O., Nuryanto \& Probosari, E. (2019). Perbedaan kadar hemoglobin pada santriwati dengan puasa daud, ngrowot, dan tidak berpuasa di Pondok Pesantren Temanggung Jawa Tengah. Journal of Nutrition College (08)2:58-64. doi : 10.14710/jnc.v8i2.23814.

Corwin, E.J. (2009). Buku saku patofisiologi. Jakarta : EGC.

Emilia. (2019). Hubungan asupan zat besi dengan status anemia pada santri putri di Pondok Pesantren Hidayatussalikin Air Item Kota Pangkalpinang Tahun 2017. Jurnal Kesehatan Poltekkes Kemenkes RI Pangkalpinang (07)2:6469. Doi : 10.32922/jkp.v7i2.88.

Husnah, N., Indriasari, R., \& Jafar, N. (2014). Hubungan makanan sumber heme dan non heme terhadap kadar hb remaja putri SMA 10 Makassar Tahun 2014. Skripsi. Universitas Hassanuddin.

Jaelani, M., Simanjutak, B.Y., \& Yuliantini, E. (2017). Faktor risiko yang berhubungan dengan kejadian anemia pada remaja putri. Jurnal Kesehatan 08 (3) 358-368. https://doi. org/10.26630/jk.v8i3.625

Junengsih \& Yuliasari. (2017). Hubungan asupan zat besi dengan kejadian anemia pada remaja putri SMU 98 di Jakarta Timur. Jurnal Ilmu dan Teknologi Kesehatan. Vol 5(1). https://doi. org/10.32668/jitek.v5i1.68

Kaimudin, N., Lestari, H., \& Afa, J. (2017). Skrining dan determinan kejadian anemia pada remaja putri SMA Negeri 3 Kendari Tahun 2017. JIMKESMAS 2 (6) 1-10.

Kwarta, B. (2019). Calcium and iron absorption : invitro studies. International Journal of Medical and Biomedical Studies 3 (12) 59-61. https://doi. org/10.32553/ijmbs.v3i12.801

Marina, M., Indriasari, R., \& Jafar, N. (2015). Konsumsi tanin dan fitat sebagai determinan penyebab anemia pada remaja putri di SMA Negeri 10 Makassar. Jurnal MKMI 11 (1) 50-58.

Marya, R.K. (2013). Patofisiologi mekanisme terjadinya penyakit. Tangerang : Binarupa Aksara.

Pratiwi, E. (2016). Faktor-faktoryang mempengaruhi anemia. Skripsi. UIN Syarif Hidayatullah.

Pratiwi, R. \& Widari, D. (2018). Hubungan konsumsi sumber pangan enhancer dan inhibitor zat besi dengan kejadian anemia pada ibu hamil. Amerta Nutrition 2 (3) 283-291. https://doi. org/10.20473/amnt.v2i3.2018.283-291

Proverawati, A., \& Wati, E.K. (2011). Ilmu gizi untuk keperawatan dan gizi kesehatan. Yogyakarta : Nuha Medika.

Puji, A.E, Satriani, S, Nadimin, \& Fadliyah. (2010). Hubungan pengetahuan ibu dan pola konsumsi dengan kejadian anemia gizi pada ibu hamil di Puskesmas Kassi-kassi. Jurnal Media Gizi Pangan. Vol.X, Edisi 2.

Sayogo, S. (2011). Gizi remaja putri. Jakarta : Balai Penerbit Fakultas Kedokteran Universitas Indonesia.

Sembiring, D.B. (2017). Hubungan body image dan pola konsumsi (faktor inhibitor dan enhancer Fe) dengan status anemia remaja putri di SMA Negeri 1 Lubuk Pakam. Skripsi. Politeknik Kesehatan Medan.

Sizer, F.S. \& Whitney, E. (2013). Nutrition : concepts and controversies. USA : Wadsworth Cengage Learning.

Sya'bani, I.R.N, Sumarmi, S. (2016). Hubungan status gizi dengan kejadian anemia pada santrwati di Pondok Pesantren Darul Ulum Peterongan Jombang. Jurnal Keperawatan Muhammadiyah, 1 (2).

Widajanti, L. (2009). Buku petunjuk praktikum survey konsumsi gizi. Semarang : Universitas Diponegoro.

World Health Organization (WHO). (2013). Worldwide prevalency of anemia WHO global database on anemia. Geneva : WHO Press.

World Health Organization (WHO). (2015). The global prevalence of anemia in 2011. Geneva: WHO Press. 